\title{
Effects of Early Compost Application on No-Till ORganic SOYBEAN $^{1}$
}

\author{
Resposta à Antecipação da Adubação com Composto Orgânico na Soja Orgânica em Plantio \\ Direto
}

\author{
PENHA, L.A.O. ${ }^{2}$, KHATOUNIAN, C.A. ${ }^{3}$ and FONSECA, I.C.B. ${ }^{4}$
}

\begin{abstract}
Weed control has always been an important issue in agriculture. With the advent of no-till systems, soil erosion was reduced but herbicide use was increased. Organic no-till systems try to adjust reduced erosion to the no use of herbicides. Nevertheless, this adjustment is limited by the cost of mechanical weed control. This cost may be reduced by improved cultural weed control with cover crops mulches. In this paper we report a study on the application of compost manure on an oats winter cover crop, preceding soybean, instead of on the soybean summer crop. Treatments comprised a control without compost manure, and compost manure doses of 4 and $8 \mathrm{Mg} \mathrm{ha}^{-1}$ applied either on oats in winter or soybean in summer, organized in a randomized block design, with five replications. In summer, plots were split into weed-controlled or not controlled subplots. The timing of application and the manure doses did not affect the oats biomass or the soybean performance. However, in summer, without water stress, the application of manure at $8 \mathrm{Mg} \mathrm{ha}^{-1}$ directly on soybean has reduced weed biomass in this crop.
\end{abstract}

Keywords: Euphorbia heterophylla, oats, Avena spp., weed, cover crop, manure.

RESUMO - O controle de plantas daninhas sempre foi um fator importante na agricultura. Com o advento do plantio direto reduziu-se a erosão do solo, mas houve aumento no uso de herbicidas. $O$ plantio direto orgânico busca conciliar o controle da erosão com a eliminação do uso de herbicidas, porém o custo de produção é onerado pela necessidade de controle mecânico das plantas daninhas. Esse custo poderia ser reduzido por um melhor controle cultural com palhas produzidas por plantas de cobertura no inverno. Neste trabalho, antecipou-se a adubação da soja para a aveia, aplicando na aveia o adubo que seria aplicado na soja, de modo a aumentar a quantidade de palha de aveia sobre a qual a soja seria semeada no verão seguinte. O delineamento experimental foi em blocos ao acaso com parcelas subdivididas. Os tratamentos foram uma testemunha sem adubação e duas doses de adubação orgânica: 4 e $8 \mathrm{Mh} \mathrm{ha}^{-1}$ e aplicados apenas na aveia (inverno) ou apenas na soja (verão). No verão, os cinco tratamentos foram divididos em subparcelas: com e sem controle de plantas daninhas. A época de aplicação e a dose do adubo não afetaram a biomassa da aveia nem o rendimento da soja. Entretanto, em verão sem restrição hídrica, a dosagem de $8 \mathrm{Mg} \mathrm{ha}^{-1}$ aplicada diretamente na soja resultou em menor biomassa de plantas daninhas nessa cultura.

Palavras-chave: Euphorbia heterophylla, aveia, Avena spp., planta daninha, adubação orgânica, planta de cobertura.

\section{INTRODUCTION}

Weed control is currently very expensive and requires considerable input in terms of energy resources, particularly the production of organic soybeans, where herbicides are not used. In this mode of production, weed control has been achieved with a sequence of operations. Soil tillage is the current practice which eliminates weeds prior to sowing, and

1 Recebido para publicação em 23.2.2011 e aprovado em 22.9.2011.

2 Pesquisador, Dr., Área de Fitotecnia, Instituto Agronômico do Paraná - IAPAR, Caixa Postal 481, 86001-970 Londrina-PR, <odenath@iapar.br>; ${ }^{3}$ Professor, Ph.D., Dep. de Agricultura, Escola Superior de Agronomia Luiz de Queiroz - ESALQ/USP, Piracicaba-SP, <armenio@esalq.usp.br>; ${ }^{4}$ Professora, Dra., Dep. de Agronomia, Universidade Estadual de Londrina - UEL, Londrina-PR, <inescbf@uel.br>. 
PENHA, L.A.O. et al.

is followed by mechanical methods during the crop cycle, the last one being by hoeing or picking. This weed management is costly, reaching $30 \%$ of the cost of production.

An alternative would be to increase the effectiveness of cultural weed control with crop mulches produced in winter, since their biomass can greatly reduce the germination and development of weed seeds and seedlings in the subsequent crop. No-till farming with better weed control would foster organic notill farming because it would combine the control of erosion to no use of herbicides.

The suppressive effect of crop mulches on weeds is proportional to their biomass on the soil surface; therefore, practices which increase the yield of winter cover crops biomass can improve the control of weeds in the subsequent summer. This correlation has been reported for several species (Bond \& Grundy, 2001; Khatounian, 2004; Melander et al., 2005; Charles et al., 2006).

The research line attempting to increase cover crops biomass production have been focused on the selection of species better adapted to local soil and climatic conditions, the use of cover crop association, and cover crop fertilization. In the Sate of Parana, Southern Brazil, oats species have been extensively studied and are indicated as cover crops due to their hardiness to pests, diseases and harsh environmental conditions, which result in high biomass production (Chaves \& Calegari, 2001; Santos et al., 2006; Silva et al., 2007; Torres et al., 2008).

In Paraná, the fertilization in no-till soybean is typically coupled with its sowing. Cover crops are sown in the preceding winter, and are managed later with a roller knife to produce the layer of mulch that suppresses weeds in subsequent crop. Since oat responds to fertilization, applying fertilizers on oats in winter, instead of on soybean in summer, could result in better weed control in soybean.

Although the current practice is to plant and fertilize soybean simultaneously, there would be clear advantages of separating these operations. Anticipated fertilization speeds up the plantig, since it requires less time to recharge the planter with fertilizer, propitiating more timely planting (Matos et al., 2006). In addition, in several studies the residual effect of early fertilization was equivalent to the fertilization at sowing date, in crops as diverse as corn (Eghball \& Lesoing, 2000; Mugwira et al., 2002) and chickpeas (Singh et al., 1999). More specifically with soybean, Lantmann et al. (1997) found that P fertilization on wheat, in winter, was enough for a full soybean yield in the subsequent summer. Similar results were obtained with K fertilization (Foloni \& Rosolem, 2008). Using organic fertilizers, Mcandrews et al. (2006) observed strong residual effects on soybean.

In this research, the possibility of applying fertilizer on an oats cover crop in winter, preceding soybean, was explored to attempt to optimize both weed control and commercial crop yield under organic management.

\section{MATERIAL AND METHODS}

The experiment was conducted in 2006-2007 and 2007-2008 seasons at the experimental station of Iapar in Londrina, PR (latitude $23^{\circ} 27^{\prime} \mathrm{S}$, longitude $51^{\circ} 57^{\prime} \mathrm{W}$ and altitude of $585 \mathrm{~m}$ ). The rainfall during the experimental period is presented in Figures 1 and 2.

The experiment was arranged in a randomized block design using split plots and five replications. The main plot treatments were: an unfertilized control, two levels of organic fertilizer applied on oats: 4 e $8 \mathrm{Mg} \mathrm{ha}^{-1}$; and two levels of organic fertilizer applied on soybean: 4 and $8 \mathrm{Mg}^{-1}$. Schematically:

$\begin{array}{ll}\text { Oats in winter } & \text { Soybean in summer } \\ \text { Without fertilizer } & \text { Without fertilizer } \\ 4 \mathrm{Mg} \mathrm{ha}^{-1} & \text { Without fertilizer } \\ 8 \mathrm{Mg} \mathrm{ha}^{-1} & \text { Without fertilizer } \\ \text { Without fertilizer } & 4 \mathrm{Mg} \mathrm{ha}^{-1} \\ \text { Without fertilizer } & 8 \mathrm{Mg} \mathrm{ha}^{-1}\end{array}$

In summer, treatments were split into weed-free and unweedded subplots.Each subplot was 4 by $4 \mathrm{~m}$. The shoot dry biomass of oats, soybean and weeds, and soybean grain yield were assessed. The shoot of oats plants were collected at the end of its cycle, and those 


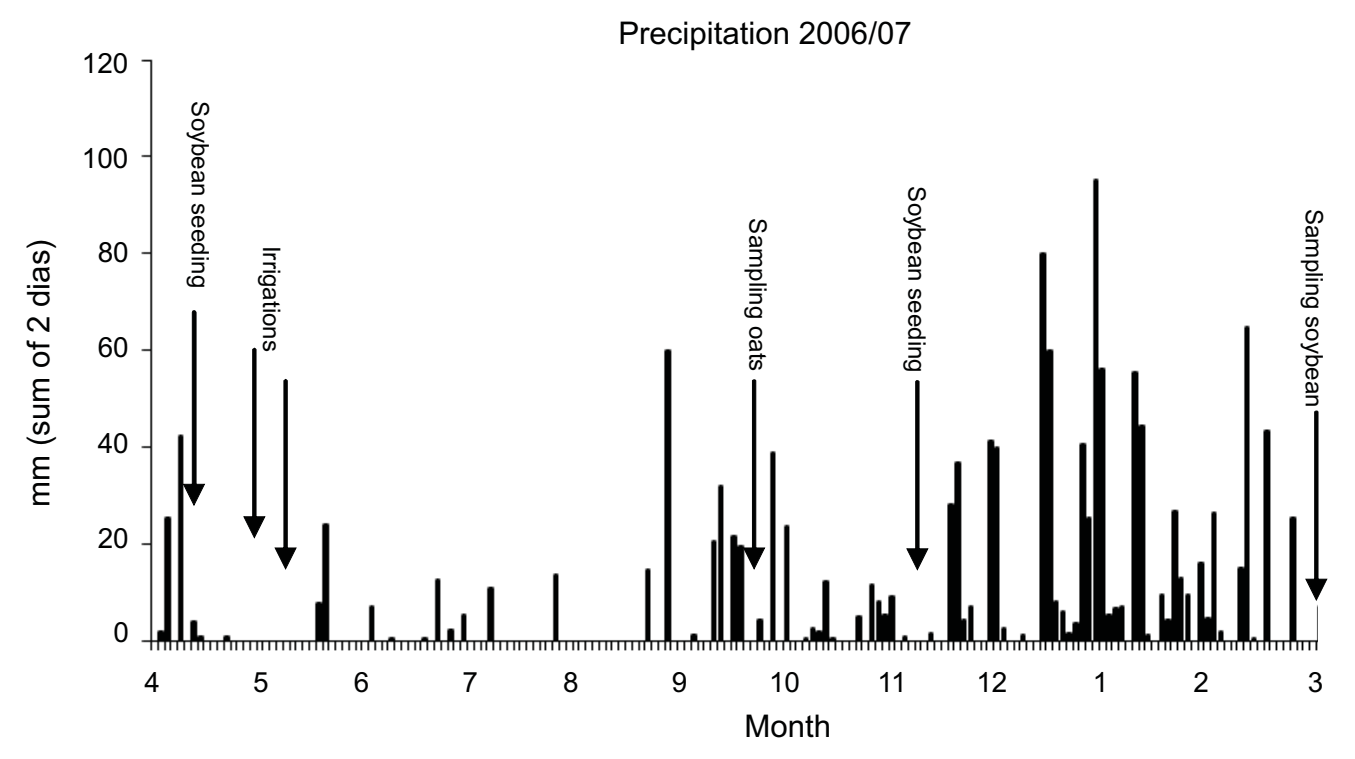

Source: IAPAR (2009).

Figure 1 - Precipitation and timing of operations in 2006/07.

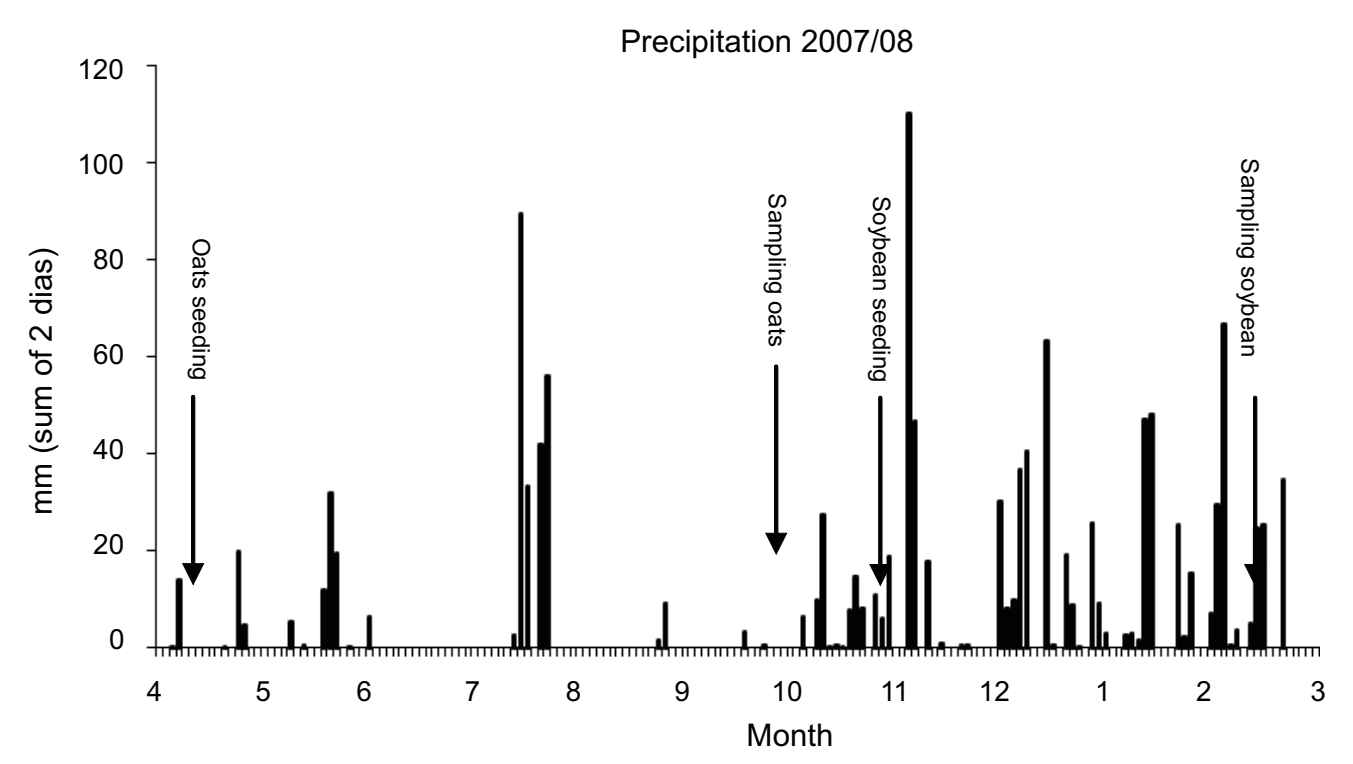

Source: IAPAR (2009).

Figure 2 - Precipitation and timing and operations in 2007/08.

from weeds and soybean were collected at soybean maturity. In each subplot, oats and weed plants were cut by hand at the ground level. After sampled, plants were dried at $65^{\circ} \mathrm{C}$ for 72 hours to constant weight. For discussion purposes, the sum of the biomass of soybean and weed was named total biomass.
To avoid the cumulative effect of fertilization over years, the experiment was conducted in a different field each season. So that, the organic fertilizer application effect on the first year was possible to be assessed.. The organic fertilizer was a cattle manure (Table 1) applied before sowing oats (winter), 
Table 1 - Nutrient contents of the organic fertilizer $\left(\mathrm{g} \mathrm{kg}^{-1}\right)$

\begin{tabular}{|c|c|c|c|c|c|c|}
\hline \multirow{2}{*}{$\begin{array}{l}\text { Nutrients } \\
\text { per year }\end{array}$} & $\mathrm{N}$ & $\mathrm{P}$ & K & $\mathrm{Ca}$ & $\mathrm{Mg}$ & \multirow{2}{*}{$\begin{array}{c}\text { Moisture } \\
(\%) \\
\end{array}$} \\
\hline & \multicolumn{5}{|c|}{$\left(\mathrm{g} \mathrm{kg}^{-1}\right)$} & \\
\hline 2006-2007 & 14.56 & 12.37 & 3.60 & 81.16 & 2.86 & 12 \\
\hline $2007-2008$ & 12.30 & 3.90 & 10.00 & 13.40 & 4.10 & 46 \\
\hline
\end{tabular}

or prior to soybean planting (summer). Soil chemical analysis for both seasons (Table 2) revealed chemical conditions similar to those of commercial soybean production system in the region. To homogenize weed infestation, Euphorbia heterophylla was superficially sown at 800 seeds $\mathrm{m}^{-2}$ in the whole experimental area, immediately before sowing oats.

Plots consisted of 20 lines of oats, $8 \mathrm{~m}$ long, spaced $0.2 \mathrm{~m}\left(4 \times 8=32 \mathrm{~m}^{2}\right)$, sown at $60 \mathrm{~kg}$ of seeds ha ${ }^{-1}$ of a $1: 1$ mixture of Avena strigosa (black oats) IAPAR-61 and Avena sativa (white oats) IPR-126 seeds, on a weight basis. Oats plants were managed with a roller knife one week before planting soybeans. For evaluation purposes, the four lateral lines of oats on each side of the plot and the first meter of all lines at the tops were discarded. Oats biomass was assessed with three square samplings of $0.25 \mathrm{~m}^{2}$ per plot. In the soybean crop, in summer, the $32 \mathrm{~m}^{2}$ plots received 10 lines of soybean BRS 257, spaced $0.4 \mathrm{~m}$. Two lateral lines on each side and the top one meter of lines were discarded for experiment purposes.

The research tried to simulate the current commercial crop conditions in the region, in which do not include irrigation. However, due to severe water stress in the winter of 2006, two irrigations of $30 \mathrm{~mm}$ were applied at the beginning of oats cycle (Figure 1), with the sole purpose of avoiding total loss of the crop, but not to achieve full crop potencial. In both seasons, a weeding was carried out soon after planting soybean to standardize the experimental condition. Later, weeding was done only in weed-free sub-plots. Data were submitted to analysis of variance, treatment differences were determined by Tukey test at $5 \%$, and correlation studies were explored.

\section{RESULTS AND DISCUSSION}

\section{Oats Biomass}

There was no difference in oats biomass in response to doses of organic fertilizer, neither in 2006 nor in 2007 (Figure 3). This result differs from those reported by Santi et al. (2003), Santa Maria-RS, who found a quadratic response of dry matter to fertilization with urea.

The difference of results may be due to drought, which was severe in Londrina, in both seasons. The total rainfall during the oats growth period in 2006 was $97 \mathrm{~mm}$ in the first four months (IAPAR, 2009), which added to $60 \mathrm{~mm}$ applied results in $157 \mathrm{~mm}$. This is not enough for the full expression of oats potential, which is achieved with approximately $480 \mathrm{~mm}$ (Bacchi et al., 1996).

In the second season, rainfall summed up $352 \mathrm{~mm}$ during the cycle of oats, which may explain the difference in biomass production between years. However, even in 2007, rainfall was insufficient for oats full development, and possibly insufficient for a good decomposition of the organic fertilizer.

Highest oats biomass yield were reported by Primavesi et al. (2002) and Luz et al. (2008), the latter authors emphasizing the superiority of irrigation to promote increased biomass production.

There were no differences in oats biomass, so it was not possible to assess the effect of the mulch quantity on weed suppression. Other authors (Theisen et al., 2000; Khatounian, 2004) who studied this subject used artificial doses of oats mulches to assess

Table 2 - Soil results from chemical analysis

\begin{tabular}{|c|c|c|c|c|c|c|c|c|c|c|}
\hline \multirow{2}{*}{ Year } & $\mathrm{P}$ & $\mathrm{C}$ & $\mathrm{pH}$ & $\mathrm{Al}$ & $\mathrm{Al}+\mathrm{H}$ & $\mathrm{Ca}$ & $\mathrm{Mg}$ & $\mathrm{K}$ & $\mathrm{T}$ & \multirow{2}{*}{$\frac{\mathrm{V}}{(\%)}$} \\
\hline & $\left(\mathrm{mg} \mathrm{dm}^{-3}\right)$ & $\left(\mathrm{g} \mathrm{dm}^{-3}\right)$ & $(\mathrm{CaCl})$ & \multicolumn{6}{|c|}{$\left(\mathrm{cmol}_{\mathrm{c}} \mathrm{dm}^{-3}\right)$} & \\
\hline 2006-2007 & 3.7 & 16.75 & 5.3 & 0.0 & 4.27 & 6.02 & 2.67 & 0.75 & 13.71 & 68.85 \\
\hline 2007-2008 & 5.3 & 15.81 & 5.3 & 0.0 & 3.97 & 3.92 & 2.63 & 0.50 & 11.02 & 63.97 \\
\hline
\end{tabular}




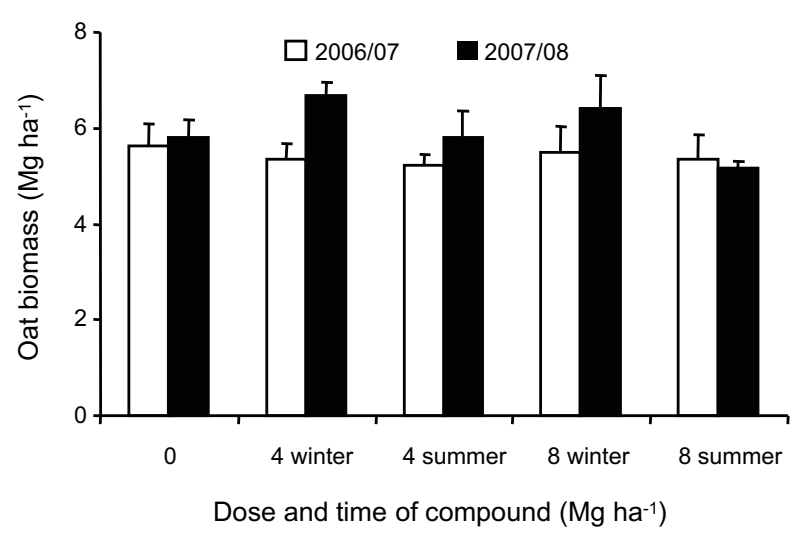

Figure 3 - Oat biomass produced with different doses and time of application of organic fertilizer.

its suppressive effects, while we attempted to use natural mulch production under different managements.

\section{Soybean Biomass and Total Biomass}

Total biomass is the result of the primary productive capacity of the system. Moreover, when two or more species come into competition, the breadth of their ecological niches decreases, so as to reduce competition (Dajoz, 2005). The result of weed and soybean biomasses (mulch + grains), with and without weeding, are presented in Figures 4 to 7 .

In both years, there was no effect of either the timing or the quantity of fertilizer application on the soybean biomass and grain yield. In 2006/07, weed control affected all treatments, but in 2007/08 weed control during crop growth benefitted soybean only in the treatment with $8 \mathrm{Mg} \mathrm{ha}^{-1}$ of fertilizer applied in winter.

In terms of mineral nutrient economy, differences in biomass should be attributed to nutrients other than $\mathrm{N}$ because soybean is very efficient in symbiotic $\mathrm{N}$ fixation. Therefore, considering soil chemical analyses, (Table 2), and the relatively small quantities of nutrients applied with the organic fertilizer, no significant effect was expected. However, when organic fertilizer was applied in summer, there was a consistent increase of $140 \mathrm{~kg} \mathrm{ha}^{-1}$ in soybean grain yield compared to the application in winter. We hypothesize

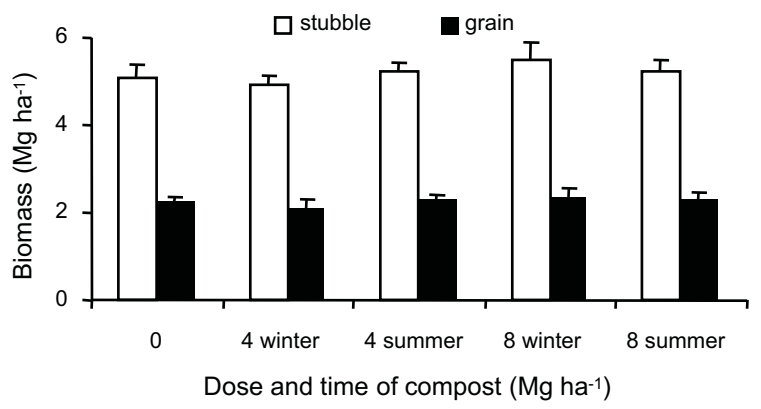

Figure 4 - Soybean biomass (stubble + grains) in the 2006/ 2007.

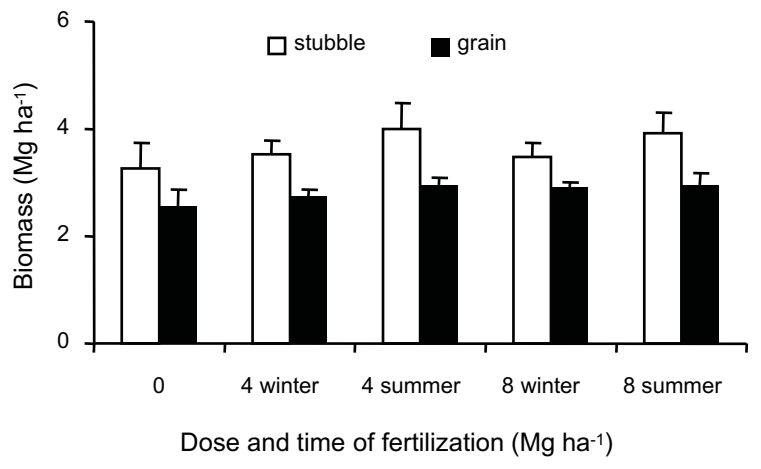

Figure 5 - Soybean biomass (stubble + grains) in the 2007/2008 crop.

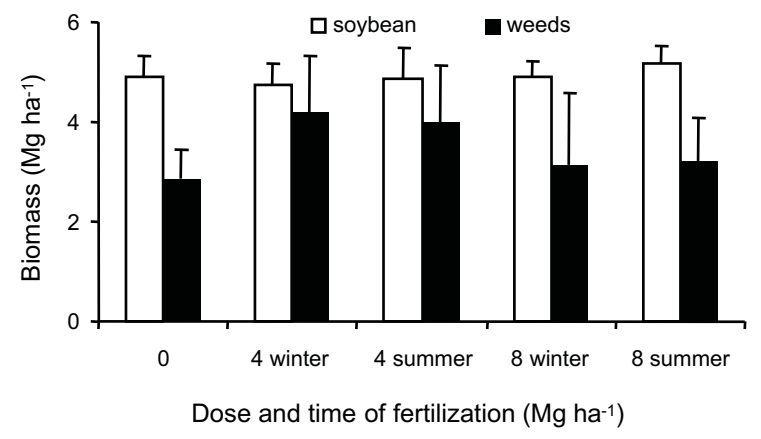

Figure 6 - Soybean and weed biomass, without weed control, 2006-2007.

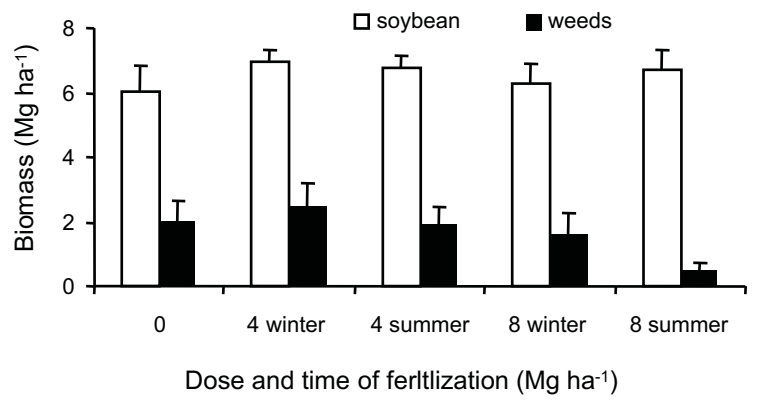

Figure 7 - Soybean and weed biomass, without weed control, 2007-2008. 
that this increase is due to $\mathrm{N}$, which, when fertilizer were applied in winter, could be immobilized in the oat mulch or lost otherwise. In no-till maize, there are reports of lower production after oats when $\mathrm{N}$ is not applied to compensate the restrictive effect of oats on this nutrient (Silva, 2007).

In fact, although soybean is highly efficient in symbiotic $\mathrm{N}$ fixation, it can respond to nitrogen fertilization. In the initial phases of crop growth, this response could be attributed to compensation of the time required for the stablishment of of Bradrizobium, responsible for $\mathrm{N}$ fixation. Nonetheless, there are studies contesting this effect, concluding for no response in terms of ultimate grain yield at any time of $\mathrm{N}$ application (Crispino et al., 2001; Aratan et al., 2008).

In $2007 / 08$, the total biomass of the treatment with $8 \mathrm{Mg} \mathrm{ha}^{-1}$ of organic fertilizer in summer was lower than those from other treatments (Figure 3). This result was due to lower weeds biomass production. The use of 8 $\mathrm{Mg} \mathrm{ha}^{-1}$ of organic fertilizer at planting increased the relative competitive ability of soybean in the soybean-weed complex, but this increase was not enough to result in crop yield differences.

When weeds were not controlled, soybean biomass and grain yield were significantly lower than in weed-free conditions, and no effect of the early fertilization was detected. Therefore, weed control is much more important than the timing of fertilizer application. These results converge to the observations of Rizzardi et al. (2004).

Our results indicated that under water stress, oats fertilization did not suppress the competition between crop and weeds. They also show that the time of application of organic fertilizer was not relevant for soybean yield, with or without weed control.

\section{Weed Biomass}

The competitive effect of weeds is highly correlated with its biomass (Meschede et al., 2004). The dry biomass of E. hetrephylla and other weeds, sampled during the soybean crop in 2006/07 and 2007/08, are shown in Figures 8 and 9.
Total biomass of the weed E. hetrephylla at soybean harvest was smaller with the highest dose of organic fertilizer applied directly on soybean. It is supposed that either soybean was more competitive, or the weeds were less so, or both, with fertilization in summer, resulting in an advantage of soybean over weeds.

Indeed, as a plant species, soybean is inherently a highly competitive plant, with higher potential of biomass production, greater leaf area index and greater efficiency in converting intercepted radiation into biomass, compared to E. hetrephylla. (Santos et al., 2003).

In addition, Procópio et al. (2002) found that soybean is more efficient in the use of water than E. hetrephylla, which was the most important weed species in the experiments. In another study, Procópio et al. (2003) also found that soybean presents a higher rate of leaf expansion than E. hetrephylla.

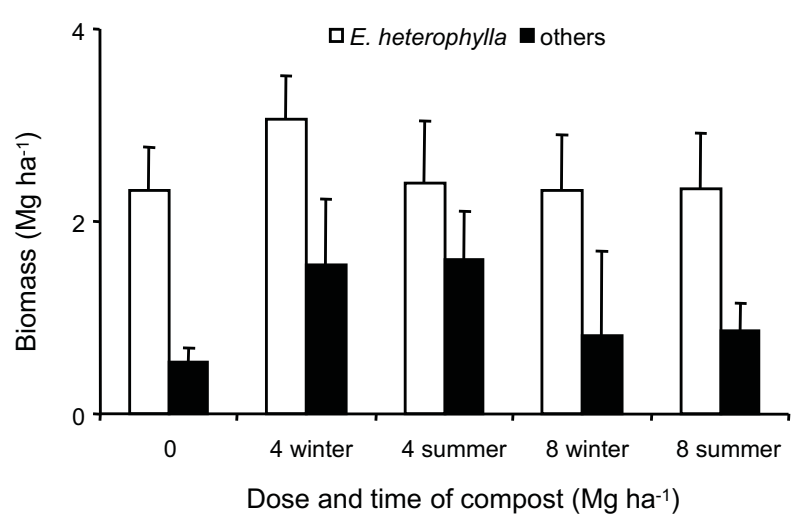

Figure 8 - Biomass of E. heterophylla other weeds at soybean harvest, 2006-2007.

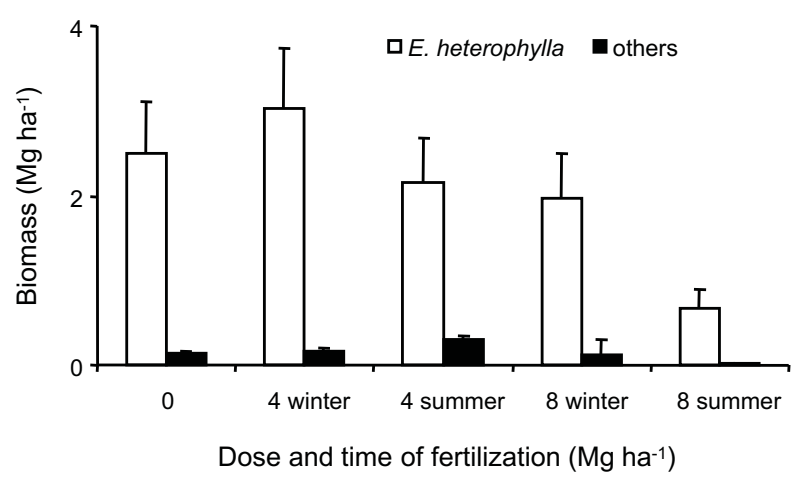

Figure 9 - Biomass of E. heterophylla and other weeds at soybean harvest, 2007/2008. 


\section{Soybean Yield, general appraisal}

Considering the results of 2006-2007 and 2007-2008 altogether, the grain yield of weedfree soybean correlated positively with oats mulch (Figure 10), with an increase of $889 \mathrm{~kg}$ of soybeans per $\mathrm{Mg}$ of oats mulch.

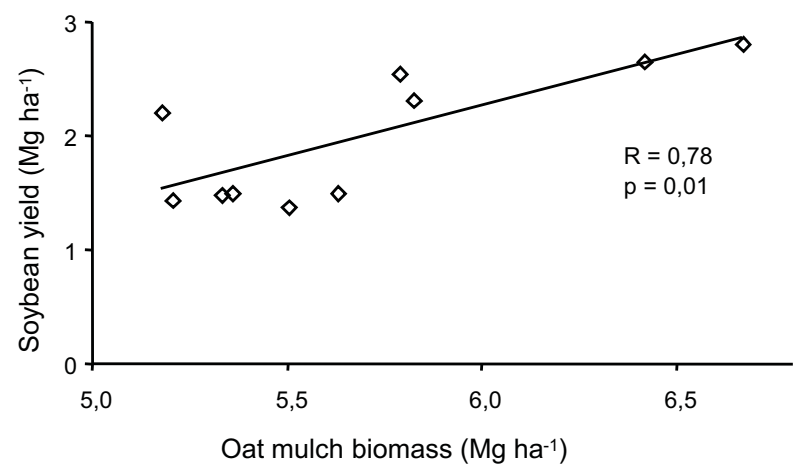

Figure 10 - Correlation of soybean yield, without weeding, and oat mulch biomass. Combined data from 2006-2007 and 2007-2008.

Weed-free soybean had benefits from both the suppression of weed competition and the abiotic effects of oats mulch, such as the narrower range in soil temperature, lower maximum soil temperature and higher water availability. Soybean is a plant with relatively high efficiency in water use (Procópio et al., 2002), which means that even small increases in water availability is likely to result in increased crop biomass and yield. However, Bortoluzzi \& Eltz (2001) found no significant difference in soybean yield with and without oats mulch. The absence of response to mulch can be related with the quantity of mulch, which was $4.17 \mathrm{Mg} \mathrm{ha}^{-1}$ in their study, while in ours it ranged from 5.7 to $7.7 \mathrm{Mg} \mathrm{ha}^{-1}$.

In a general, the results showed that organic fertilization did not affect oats biomass production, nor soybean yield was affected by the time and the doses of organic fertilizer application. However, the $8 \mathrm{Mg} \mathrm{ha}^{-1}$ of organic fertilizer applied directly on soybean in the summer did reduce weed biomass on the crop.

\section{LITERATURE CITED}

ARATAN, R. G. et al. Adubação nitrogenada em soja na implantação do sistema Plantio direto. Biosci. J., v. 24, n. 3, p. 31-38, 2008.
BACCHI, O. O. S et al. Balanço hídrico em cultura de aveia forrageira de inverno na região de São Carlos-SP. Sci. Agric., v. 53, n. 1, p. 172-178, 1996.

BOND, W.; GRUNDY, A. C. Non-chemical weed management in organic famring systems. Weed Res., v. 41, n. 5, p. 383-405, 2001.

BORTOLUZZI, E. C.; ELTZ, F. L. F. Manejo da palha de aveia preta sobre as plantas e rendimento de soja em plantio direto. Ci. Rural, v. 31, n. 2, p. 237-243, 2001.

CHARLES, K. S. et al. Integration of cover crops and fertilizer rates for weed management in celery. Weed Sci., v. 54, n. 2, p. 326-334, 2006.

CHAVES, J. C. D.; CALEGARI, A. Adubação verde e rotação de culturas. Inf. Agropec., v. 22, n. 212, p. 53-60, 2001.

CRISPINO, C. C. et al. Adubação nitrogenada na cultura da soja. Londrina: Embrapa Soja, 2001. (Comunicado Técnico, 75)

DAJOZ, R. As populações, as comunidades e os fatores ecológicos In: DAJOZ, R. Princípios de ecologia. Porto Alegre, Artmed, 2005. p. 113-132.

EGHBALL, B.; LESOING, G. W. Viability of weed seeds following manure windrow composting. Compost Sci. Utiliz., v.8 n. 1, p. 46-53, 2000.

FOLONI, J. S. S.; ROSOLEM, C. A. Produtividade e acúmulo de potássio na soja em função da antecipação da adubação potássica no sistema plantio direto. R. Bras. Ci. Solo, v. 32, n. 4, p. 1549-1561, 2008.

IAPAR. [Online] Monitoramento agroclimático do Paraná. Disponível em: <http://www.iapar.br/Sma/ Monitoramento_Mensal.htm>. Acesso em: 20 abr. 2009.

KHATOUNIAN, C. A. Weed control in no-till organic soybeans in southern Brazil. Doctoral Thesis - Iowa State University, Iowa, 2004, 104 p.

LANTMANN, A. F. et al. Produtividade do trigo em sucessão a soja não fertilizada em latossolo roxo distrofico. Pesq. Agropec. Bras., v. 32, n. 3, p. 257-265, 1997.

LUZ, P. H. C. et al. Resposta da aveia preta (Avena strigosa) à irrigação por aspersão e adubação nitrogenada. Acta Sci. Agron., v. 30, n. 3, p. 421-426, 2008.

MATOS, M. A.; SALVI, J. V.; MILAN, M. Pontualidade na operação de semeadura e a antecipação da adubação e suas influências na receita líquida da cultura da soja. Eng. Agríc., v. 26, n. 2, p. 493-501, 2006. 
MCANDREWS, G. M. et al. Residual effects of composted and fresh solid swine manure on soybean growth and yield. Agron. J., v. 98, n. 4, p. 873-882, 2006.

MELANDER, B.; RASMUSSEN, I. A.; BÀRBERI, P. Integrating physical and cultural lmethods of weed control examples from european research. Weed Sci., v. 53, n. 3, p. 369-381, 2005.

MESCHEDE, D. K. et al. Período anterior a interferência de plantas daninhas em soja: estudo de caso com baixo estande e testemunhas duplas. Planta Daninha, v. 22, n. 2, p. 239-246, 2004.

MUGWIRA, L.M.; NYAMANGARA, J.; HIKWA, D. Effects of manure and fertilizer on maize at a research station and in a smallholder (peasant) area of Zimbabwe. Comm. Soil Sci. Plant Anal., v. 33, n. 3, p. 379-402, 2002

PRIMAVESI, A. C. et al. Adubação de aveia em dois sistemas de plantio. Pesq. Agropec. Bras., v. 37, n. 12, p. 1773-1778, 2002.

PROCÓPIO, S. O. et al. Análise do crescimento e eficiência no uso da água pelas culturas de soja e feijão e por plantas daninhas. Acta Sci., v. 24, n. 5, p. 1345-1351, 2002.

PROCÓPIO, S. O. et al. Desenvolvimento foliar das culturas da soja e do feijão e de plantas daninhas. Ci. Rural, v. 33, n. 2, p. 207-211, 2003.

RIZZARDI, M. A. et al. Interferência de populações de Euphorbia heterophylla e Ipomoea ramosissima isoladas ou em misturas sobre a cultura de soja. Planta Daninha, v. 22, n. 1, p. 29-34, 2004.
SANTI, A.; AMADO, T. J. C.; ACOSTA, J. A. A. Adubação nitrogenada na aveia preta. I - Influência na produção de matéria seca e ciclagem de nutrientes sob sistema plantio direto. R. Bras. Ci. Solo, v. 27, n. 6, p. 1075-1083, 2003.

SANTOS, H. P.; LHAMBY, J. C. B.; SPERA, S. T. Rendimento de grãos de soja em função de diferentes sistemas de manejo de solo e de rotação de culturas. Ci. Rural, v. 36, n. 1, p. 21-29, 2006.

SANTOS, J. B. et al. Captação e aproveitametno da radiação solar pelas culturas da soja e do feijão e por plantas daninhas. Bragantia, v. 62, n. 1, p. 147-153, 2003.

SILVA, A. A. et al. Sistemas de cobertura de solo no inverno e seus efeitos sobre o rendimento de grãos do milho em sucessão. Ci. Rural, v. 37, n. 4, p. 928-935, 2007.

SINGH, G. R.; PARIHAR, S. S.; CHAURE, N. K. Response of organic manures in a rice (Oryza sativa)-chickpea (Cicer arietinum) crop sequence. Inter. Rice Res. Newsletter. v. 24, n. 3, 1999. Disponível em: <http://www.irri.org/ publications/irrn/pdfs/vol24no3/IRRN24-3Cropmgt.pdf.>. Acesso em: 25 ago. 2009.

THEISEN, G.; VIDAL, R. A.; FLECK, N. G. Redução da infestação de Brachiaria plantaginea em soja pela cobertura do solo com palha de aveia-preta. Pesq. Agropec. Bras., v. 35, n. 4, p. 753-756, 2000.

TORRES, J. L. R.; PEREIRA, M. G.; FABIAN, A. J. Produção de fitomassa por plantas de cobertura e mineralização de seus resíduos em plantio direto. Pesq. Agríc. Bras., v. 43, n. 3, p. 421-428, 2008. 